\title{
Systematic Review and Meta-Analysis of Human Visceral Leishmaniasis in Iran
}

\author{
Vahid Rahmanian ${ }^{1}$, Karamatollah Rahmanian ${ }^{1}$, Abdolreza Sotoodeh Jahromi ${ }^{1}$, Saied Bokaie ${ }^{2}$ \\ ${ }^{1}$ Zoonoses Research Center, Jahrom University of Medical Sciences, Jahrom, Iran \\ ${ }^{2}$ Department of Epidemiology, Faculty of Veterinary Medicine, University of Tehran, Tehran, Iran
}

\section{SUMMARY}

Visceral leishmaniasis (VL) is a protozoan disease caused by some Leishmania donovani complex species and is considered as an endemic zoonotic parasitic disease in Iran. This study was performed to determine the prevalence of human VL in Iran. Data were systematically gathered from 1985 to 2018 in Islamic republic of Iran from the following electronic databases: PubMed, Google Scholar, Science Direct, Scopus, Web of Science, Magiran, Irandoc, Iranmedex and Scientific Information Database (SID). In total, 29 studies reporting the prevalence of VL from different areas of Iran met our suitability criteria. The $Q$ test and the I2 statistics were applied to determine heterogeneities. The Egger's and Begg's test was used to check the presence of publication bias. The pooled prevalence of VL in Iran measured by random-effects was estimated at 1\% (95\% CI:1 - 2) in urban areas, 3\% (95\% CI:2 - 4) in rural areas and 2\% (95\% CI: 2-3) in total. The majority of VL cases during the last 33 years were reported in the northwest and south provinces of Iran. There was a high degree of heterogeneity (I2= 98.2\%, $Q$ test: $\mathrm{p}=0.0002)$ and Begg's $(\mathrm{z}=3.62, \mathrm{p}<0.001)$ and Egger's (bias $=5.9,95 \% \mathrm{CI}=2.70-9.11)$ tests were significant for the study of publication bias. After correction, the total prevalence was estimated to be $0.3 \%(95 \%$ CI: 0.2 - 0.9). The prevalence of VL in Iran was $0.3 \%$, and this rate was much higher in the northwest and south of the country. These results are desirable for managing the control programs of this disease.

Key words: black fever, Leishmania infantum, kala azar, prevalence, Iran

Corresponding author:

Saied Bokaie

E-mail: sbokaie@ut.ac.ir 


\section{INTRODUCTION}

Leishmaniasis is one of the zoonotic parasitic diseases that occur in three forms: cutaneous (CL), mucosal (ML) and visceral (VL) (1).

Visceral leishmaniasis is caused by Leishmania donovani complex species. Two parasites containing Leishmania donovani ( $L$. donovani) and Leishmania infantum (L. infantum) caused VL in the old world (the Eastern Hemispher) and L. chagasi in the new world (the Western Hemispher) $(2,3)$. In different countries, it is also named infantile kala-azar, tropical splenomegaly syndrome, febrile splenic anemia and ponos (4).

Endemic VL is found in tropical and subtropical regions of Africa, Asia, the Mediterranean, southern Europe, Sudan and South America, and more than 90\% of cases are present in Bangladesh, India, Nepal, Sudan and Brazil (5).

The disease affects around 500,000 people each year and causes fatalities in 50,000 people around the world (6). In different parts of the world, various domestic and wild animals, and even human beings, are known to be the reservoirs of the disease; also, different sand fly species can act as vectors of this disease (7).

Currently, VL in Iran is considered an endemic disease and its prevalence is estimated at 0.092 per 100,000 people and its direct medical cost is $\$ 295$ per patient $(8-10)$. The VL agent in Iran is Leishmania infantum in the Mediterranean subregion and is often reported in children under the age of 12 years and more in nomads and villagers $(11,12)$. Some cases of VL have been reported with disseminated CL from southern Iran, which was caused by Leishmania tropica (13).

In Iran, dogs are domesticated hosts and jackals, wolves and foxes as wild hosts are the main reservoirs of the disease $(12,14)$. Five species of sand flies are known to be the potential vectors of VL disease, four of which are from the subgenus Larroussius and one from subgenus Paraphlebotomus (8).

Visceral leishmaniasis might be found both in symptomatic and asymptomatic forms. In some regions, latent infection is more prevalent than active clinical disease. In endemic areas of Iran, latent infections are more common than in clinical forms. In the absence of diagnosis and timely treatment of the disease in humans, especially among children, death rate is about
$98 \%$ (15 - 18). Treatment of this disease in Iran still relies on meglumine antimoniate whose effects are not the same in all cases.

The main symptoms are fever, splenomegaly and anemia, and abnormal laboratory findings include pancytopenia and hypergammaglobulinemia and hypoalbuminemia (12). For the diagnosis of this disease, the invasive methods of biopsy from the spleen, liver or bone marrow aspiration are set as the gold standards. Non-invasive diagnostic methods, such as antibody detection by direct agglutination test (DAT), indirect immunofluorescence assay (IFA) and enzyme-linked immunosorbent assay (ELISA) are presently used (17, 19, 20).

Given the rapid and unprogrammed development of cities, environmental changes, parasite resistance to conventional drugs, opportunistic parasites in immunocompromised individuals and a growing complexity of the disease symptoms, there is a need for more precise detection of the disease outbreak to manage the control programs. This study aimed to reveal the prevalence of human VL in Islamic republic of Iran.

\section{METHODS}

\section{Bibliographic search}

The search was done in databases including Pub Med, Google Scholar, Science Direct, Scopus, Web of Science, Magiran, Iran doc, Iran medex and Scientific Information Database (SID for the period 1985 to 2018. Duplicates and animal-based articles were excluded. All cross-sectional studies related to the human VL in Iran were considered. The research process is given in Figure 1.

\section{Search strategy}

The search was implemented using the keywords as follows: visceral leishmaniasis, kala azar, black fever, Leishmania infantum, anti-Leishmania antibody, epidemiology, and prevalence only or in combination in Iran, both in Persian and English language. 

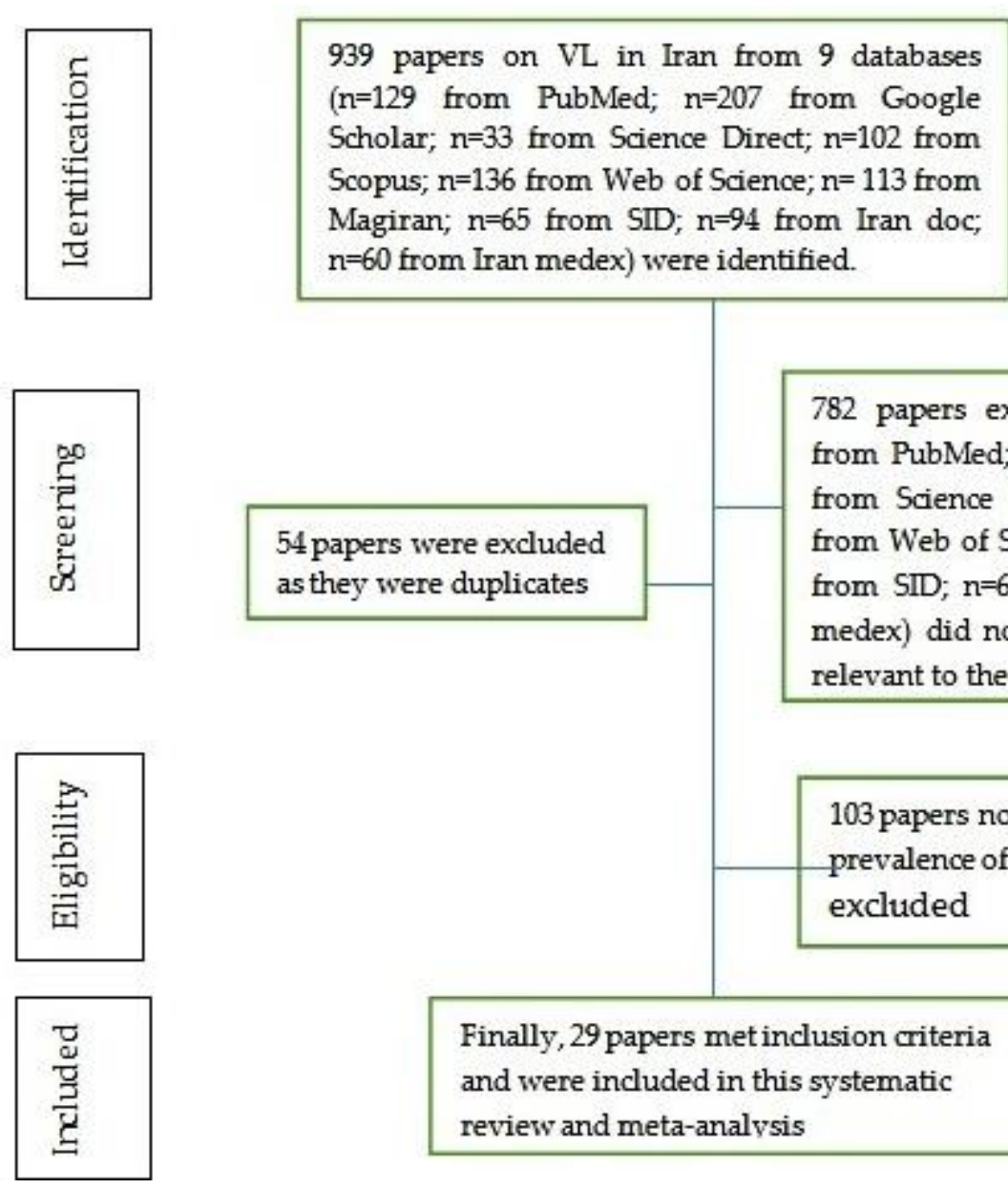

939 papers on VL in Iran from 9 databases $(n=129$ from PubMed; $n=207$ from Google Scholar; $n=33$ from Science Direct; $n=102$ from Scopus; $n=136$ from Web of Science; $n=113$ from $\mathrm{n}=60$ from Iran medex) were identified.

54 papers were excluded as they were duplicates
782 papers excluded for some reason ( $\mathrm{n}=111$ from PubMed; $n=182$ from Google Scholar; $n=28$ from Science Direct; $n=63$ from Scopus; $n=113$ from Web of Science; $n=103$ from Magiran; $n=60$ from SID; $n=69$ from Iran doc; $n=53$ from Iran medex) did not address the issues or questions relevant to the review

103 papers not dealing with the prevalence of $\mathrm{VL}$ in humans were excluded

Figure 1. A flowchart presenting the selection of the articles analyzed in this systematic review and meta-analysis

\section{Data collection}

Based on the mentioned strategy, the search was performed in nine databases. Subsequently, the collected articles were carefully evaluated for epidemiological parameters; finally, 29 articles met study inclusion criteria, including the accessibility of full text, study of human VL prevalence, as well as the selection of subjects by random or census sampling methods. Exclusion criteria were: data inconsistencies, use of inappropriate statistical methods, unspecified sampling methods, non- random sampling method, VL in non-human cases, and articles published before 1985. The data extracted from the articles were the names of authors (s), date of study, type of study, demographic information such as age groups as well as the geographical area of the study, the number of subjects examined, the number of seropositive patients and the prevalence and laboratory method used in the study (Table 1). The findings were recorded in each database based on a search made from January to July of 2018. 
Table 1. Papers that met the eligibility criteria of this systematic review and meta-analysis

\begin{tabular}{|c|c|c|c|c|c|c|c|c|c|c|}
\hline $\begin{array}{l}\text { O } \\
\mathbf{Z}\end{array}$ & 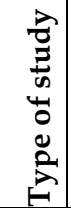 & 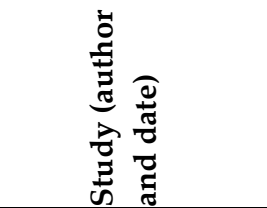 & 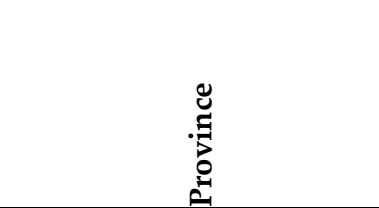 & 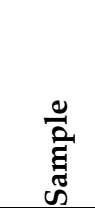 & 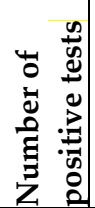 & 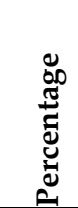 & 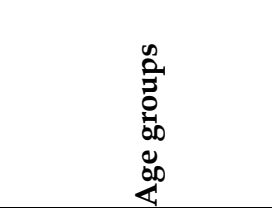 & 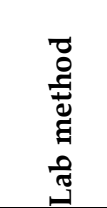 & 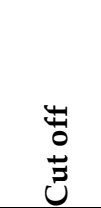 & $\stackrel{\longleftarrow}{\simeq}$ \\
\hline 1 & cs & Asfaram 2017 & Ardabil & 600 & 23 & 3.8 & $20-40$ and $40>$ & DAT & $1: 3200$ & $(24)$ \\
\hline 2 & cs & Mohebali 2011 & $\begin{array}{l}\text { Northwest,Northeast,South } \\
\text { and Southeast parts of Iran }\end{array}$ & 9369 & 403 & 4.3 & $12 \leq$ & DAT & $1: 3200$ & $(25)$ \\
\hline 3 & CS & Faghihenaeini 2002 & Tehran & 925 & 1 & 0.1 & $10<$ & DAT & $1: 3200$ & $(26)$ \\
\hline 4 & cs & Ashkanifar 2016 & khorasan Razavi and North & 442 & 22 & 5.22 & $12<$ & DAT & $1: 3200$ & $(27)$ \\
\hline 5 & cs & Edrissian 2003 & $\begin{array}{c}\text { Ardabil, East Azarbaijan and } \\
\text { Bushehr }\end{array}$ & 19693 & 1274 & 6.47 & $12<$ & DAT & $1: 3200$ & $(28)$ \\
\hline 6 & cs & Mohami 2006 & Ardabil & 1155 & 7 & 0.6 & $\begin{array}{c}12<\text { and } 10 \% \text { of } \\
\text { adults }\end{array}$ & DAT & $1: 3200$ & $(29)$ \\
\hline 7 & Cs & Sarkari 2010 & Booyerahmad & 1628 & 50 & 3.1 & $10 \leq$ & DAT & $1: 3200$ & $(30)$ \\
\hline 8 & CS & Mohebali 2017 & Ardabil & 180 & 0 & 0 & $\geq 13$ & DAT & $1: 3200$ & $(31)$ \\
\hline 9 & CS & Fakhar 2008 & Fars & 802 & 13 & 1.62 & $5-10$ and $10>$ & DAT & $1: 3200$ & (32) \\
\hline 10 & Cs & Fakhar 2006 & Fars & 321 & 6 & 1.86 & $\begin{array}{c}10<\text { and } 10 \% \text { of } \\
\text { adults }\end{array}$ & DAT & $1: 3200$ & (33) \\
\hline 11 & cs & $\begin{array}{l}\text { Changeni Sharafi } \\
2005 \\
\end{array}$ & Lorestan & 530 & 6 & 1.26 & $\begin{array}{c}12<\text { and } 10 \% \text { of } \\
\text { adults }\end{array}$ & DAT & $1: 3200$ & $(34)$ \\
\hline 12 & Cs & Fakhar 2014 & Golestan & 450 & 6 & 1.33 & $12<$ & DAT & $1: 3200$ & $(35)$ \\
\hline 13 & Cs & Sarkari 2015 & Fars & 2003 & 28 & 1.4 & adult & DAT & $1: 3200$ & $(36)$ \\
\hline 14 & cs & Fakhar 2010 & Fars & 376 & 32 & 8.5 & $\begin{array}{c}10<\text { and } 10 \% \text { of } \\
\text { adults }\end{array}$ & PCR & - & $(37)$ \\
\hline 15 & cs & Fakhar 2010 & Fars & 376 & 5 & 1.33 & $\begin{array}{c}10<\text { and } 10 \% \text { of } \\
\text { adults }\end{array}$ & DAT & - & $(37)$ \\
\hline 16 & $\mathrm{cs}$ & Mohebali 2011 & Kerman & 1476 & 14 & 0.95 & $\begin{array}{c}12<\text { and } 10 \% \text { of } \\
\text { adults }\end{array}$ & DAT & $1: 3200$ & $(38)$ \\
\hline 17 & cs & Fakhar 2011 & Mazandaran & 402 & 0 & 0 & $\begin{array}{c}12<\text { and } 10 \% \text { of their } \\
\text { parents }\end{array}$ & DAT & $1: 3200$ & (39) \\
\hline 18 & Cs & Hamzavi 2012 & Kermanshah & 1800 & 6 & 0.33 & $15<$ and adults & DAT & $1: 3200$ & $(40)$ \\
\hline 19 & Cs & Mohebali 2015 & Alborz & 1007 & 4 & 0.39 & $10<$ & DAT & $1: 3200$ & $(41)$ \\
\hline 20 & Cs & Layegh Gigloo 2018 & Fars & 617 & 17 & 2.75 & $12<$ and $>12$ & ELISA & & $(42)$ \\
\hline 21 & cs & Masoori 2018 & Lorestan & 800 & 5 & 0.62 & $\begin{array}{c}12<\text { and } 10 \% \text { of } \\
\text { adults }\end{array}$ & DAT & $1: 3200$ & $(43)$ \\
\hline 22 & cs & $\begin{array}{l}\text { Ebrahimzade- } \\
\text { Parikhani } 2017\end{array}$ & Ardabil & 776 & 1 & 0.13 & $12 \leq$ & DAT & $1: 3200$ & $(44)$ \\
\hline 23 & cs & Abedi 2015 & Ilam & 456 & 2 & 0.43 & $\begin{array}{c}12 \leq \text { and } 10 \% \text { of } \\
\text { adults }\end{array}$ & DAT & $1: 3200$ & $(45)$ \\
\hline 24 & Cs & Khazaei 2017 & Ilam & 872 & 20 & 2.29 & $12 \leq$ & DAT & $1: 800$ & $(46)$ \\
\hline 25 & Cs & Gorgipour 2017 & Bushehr & 1221 & 0 & 0 & $12 \leq$ & DAT & $1: 3200$ & $(47)$ \\
\hline 26 & cs & Mohebali 2003 & East Azarbaijan & 1252 & 24 & 1.9 & $\begin{array}{c}10<\text { and } 10 \% \text { of } \\
\text { adults }\end{array}$ & DAT & $1: 3200$ & $(48)$ \\
\hline 27 & CS & Alborzi 2008 & Fars & 338 & 95 & 24.5 & $10<$ & PCR & - & $(49)$ \\
\hline 28 & cs & Alborzi 2008 & Fars & 388 & 212 & 54.6 & $1-35$ & IFA & ND & $(49)$ \\
\hline 29 & cs & Mohebali 2008 & North Khorasan & 1608 & 38 & 2.36 & $\begin{array}{c}12<\text { and } 10 \% \text { of } \\
\text { adults }\end{array}$ & DAT & $1: 800$ & $(50)$ \\
\hline 30 & cs & Mohebali 2001 & Bushehr & 1496 & 51 & 3.4 & $\begin{array}{c}10<\text { and } 10 \% \text { of } \\
\text { adults }\end{array}$ & DAT & $1: 3200$ & $(51)$ \\
\hline 31 & cs & Rakhshanpour 2014 & Qom & 1564 & 1 & 0.06 & ND & DAT & $1: 3200$ & (52) \\
\hline
\end{tabular}

CS: Cross-Sectional, DAT: direct agglutination test, ELISA: enzyme-linked immunosorbent assay, IFA: indirect immunofluorescent assay, LST: Leishmanin skin test, ND: not defined, PCR: polymerase chain reaction. Ref - References 


\section{Statistical analysis}

Point estimates and their $95 \%$ CI of seroprevalence of all involved articles were calculated. The seropreva-lence (P) and standard error of mean (Se) of each study were calculated with respect to binomial distribution and studies pooled according to sample size and variance.

Regarding the fact that the seroprevalence of the three articles included in this meta-analysis was zero, the continuity correction method was used. In this method, in all groups, $\mathrm{k}=0.5$ was added to the number of subjects in all studies $(21,22)$ and then all calcu-lations, including seroprevalence and standard error, were recalculated based on new data. The mean error when using $\mathrm{k}=0.5$ was zero (23).

The Egger's and Begg's test were used to assess the presence of publication bias and whereas trim-andfill method was used to correct the publication bias. Forest plot was used to visualize the heterogeneity among papers. The heterogeneity was predictable in advance and $\mathrm{I} 2$ and $\mathrm{Q}$ test (with significance of $\mathrm{P}<0.05$ ) were used to measure the variations. With the aim to perform meta-analysis, we assumed that the included papers were random samples of the population under study and a random effects model was used. Proportions of separate studies and prevalence pool were shown by forest plots. Statistical analyses were implemented using Stata, version 12.0 (Stata Corp, College Station, TX, USA). Furthermore, the Arc GIS 10.3 software was applied to map the distribution of VL cases.

\section{RESULTS}

In total, 939 articles were obtained by searching the databases with reference to the period from July 15,
1985 to 2018; after reviewing the inclusion criteria, 29 papers met the eligibility criteria of this systematic review and meta-analysis (Table 1). All 29 articles included in this study evaluated the seroprevalence of VL in children under 12 years of age as a cross-sectional type and in adults as an active type. A total of 55,311 people were evaluated during 33 years, of which 2,498 were seropositive (Table 1).

There was a high degree of heterogeneity in estimating the prevalence of studies in meta-analysis, in which the heterogeneity was $\mathrm{I} 2=88.2 \%$ ( $\mathrm{Q}$ test: $\mathrm{p}=$ $0.0001)$ in urban areas, $I 2=99.2 \%(Q$ test: $p=0.0002)$ in rural areas and $\mathrm{I} 2=98.2 \%(\mathrm{Q}$ test: $\mathrm{p}=0.0002)$ in total.

The pooled prevalence of VL in Iran measured by random-effects meta-analysis was estimated at 1\% (95\% CI: 1 - 2) in urban areas, 3\% (95\% CI: 2 - 4) in rural area and $2 \%$ (95\% CI: $2-3$ ) in total (Figure 2).

In addition, a schematic image of the VL distribution was made based on studies conducted over the past 33 years in 14 provinces of Iran (Figure 3)

\section{Publication bias}

The Egger's and Begg's tests were applied to check the presence of publication bias. The Begg's test $(\mathrm{z}$ $=3.62, \mathrm{p}=0.001$ ) and the Egger's test (bias $=5.9,95 \% \mathrm{CI}=$ 2.70 - 9.11) indicated a significant publication bias of studies (Figure 4). The Trim-and-fill method was used to correct the meta-analysis results, and the hypothetical values of 14 censored studies were estimated using nonparametric methods and then were reported as corrected values in the final meta-analysis. The corrected seroprevalence after correction of publication bias was estimated to be $0.3 \%$ (95\% CI: 0.2 - 0.9) by random-effects method (Table 2). 


\begin{tabular}{|c|c|c|c|}
\hline \multicolumn{2}{|l|}{$\begin{array}{l}\text { Study } \\
\text { ID }\end{array}$} & \multirow[t]{2}{*}{ ES $(96 \% 6 \mathrm{Cl})$} & \multirow[t]{2}{*}{$\begin{array}{l}\% \\
\text { Weight }\end{array}$} \\
\hline Urban & $\left.\right|_{1} ^{1}$ & & \\
\hline Abedi2015-DAT & - & $0.01(-0.00,0.01)$ & 3.54 \\
\hline AsfaramR017-DAT & T & $0.04(0.02,0.05)$ & 2.79 \\
\hline Hamzavi2012 DAT & - & $0.00(0.00,0.01)$ & 3.73 \\
\hline Layegh Gigloo 2017 -EUSA & - & $0.03(0.01,0.04)$ & 3.05 \\
\hline Mas cor i 2012 -DAT & $\bullet$ & $0.01(0.00,0.01)$ & 3.60 \\
\hline Mohebali 2002 -DAT & 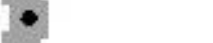 & $0.02(0.01,0.03)$ & 3.47 \\
\hline Mohebali 2008 -DAT & - & $0.01(0.00,0.01)$ & 3.68 \\
\hline Mohebali 2015 -DAT & - & $0.00(-0.00,0.01)$ & 3.49 \\
\hline Sarkari2006-DAT & $1 \bullet$ & $0.03(0.02,0.04)$ & 3.43 \\
\hline Sarkari 2015-DAT & - & $0.01(0.01,0.02)$ & 3.63 \\
\hline Subtotal (1-squared $=88.6 \%, p=0.000$ ) & 4 & $0.01(0.01,0.02)$ & 34.39 \\
\hline Rural & i & & \\
\hline Alborzi 2005 -IFAT & 1 & $0.55(0.50,0.60)$ & 0.83 \\
\hline Alborzi $2005-P C R$ & $\rightarrow-$ & $0.25(0.20,0.29)$ & 1.03 \\
\hline Ashkanifar 2015 -DAT & $1+$ & $0.05(0.03,0.07)$ & 2.41 \\
\hline Changenis harafi 2004 - DAT & - & $0.01(0.00,0.02)$ & 3.39 \\
\hline Ebrahimzade-Parkhani 2015-DAT & - & $0.00(-0.00,0.00)$ & 3.72 \\
\hline Edrissian 1997-DAT & L. & $0.08(0.06,0.07)$ & 3.71 \\
\hline Faghar 2005 -DAT & $\bullet$ & $0.02(0.00,0.04)$ & 2.81 \\
\hline Faghar 2006 -DAT & $\bullet$ & $0.02(0.01,0.02)$ & 3.42 \\
\hline Faghar 2010 -DAT & - & $0.01(0.00,0.03)$ & 3.12 \\
\hline Faghar 2010 -DAT & - & $0.00(-0.00,0.00)$ & 3.71 \\
\hline Faghar $2010-P C R$ & $11 *$ & $0.09(0.06,0.11)$ & 1.74 \\
\hline Faghar 2012-DAT & $\bullet$ & $0.01(0.00,0.02)$ & 329 \\
\hline Faghihenaeini 2002 -DAT & $\bullet$ & $0.00(0.00,0.00)$ & 3.77 \\
\hline Gorgipour 2015 -DAT & - & $0.00(-0.00,0.00)$ & 3.76 \\
\hline Khazaei 2014 -DAT & $\cdot$ & $0.02(0.01,0.03)$ & 329 \\
\hline Mohebali 1999 -DAT & | & $0.03(0.03,0.04)$ & 3.35 \\
\hline Mohebali 2007-DAT & $\bullet$ & $0.02(0.02,0.03)$ & 3.50 \\
\hline Mohebali 2009 -DAT & $1 \bullet$ & $0.04(0.04,0.05)$ & 3.69 \\
\hline Mohebali 2010-DAT & - & $0.01(0.00,0.01)$ & 3.64 \\
\hline Mohebali 2014 -DAT & - & $0.00(0.00,0.01)$ & 3.69 \\
\hline Rakhshanpour 2012 -DAT & - & $0.00(-0.00,0.00)$ & 3.76 \\
\hline Subtotal (1-squared $=99.2 \%, p=0.000$ ) & 4 & $0.03(0.02,0.04)$ & 65.61 \\
\hline Overall ( 1 -squared $=98.9 \%, p=0.000$ ) & 1 & $0.02(0.02,0.03)$ & 100.00 \\
\hline NOTE: Weights are fomrandom effects analys is & 1 & & \\
\hline$T$ & & & \\
\hline-.598 & 0 & & \\
\hline
\end{tabular}

Figure 2. Forest plot showing the proportion of human VL in urban and rural population in the Islamic Republic of Iran (random-effects) 


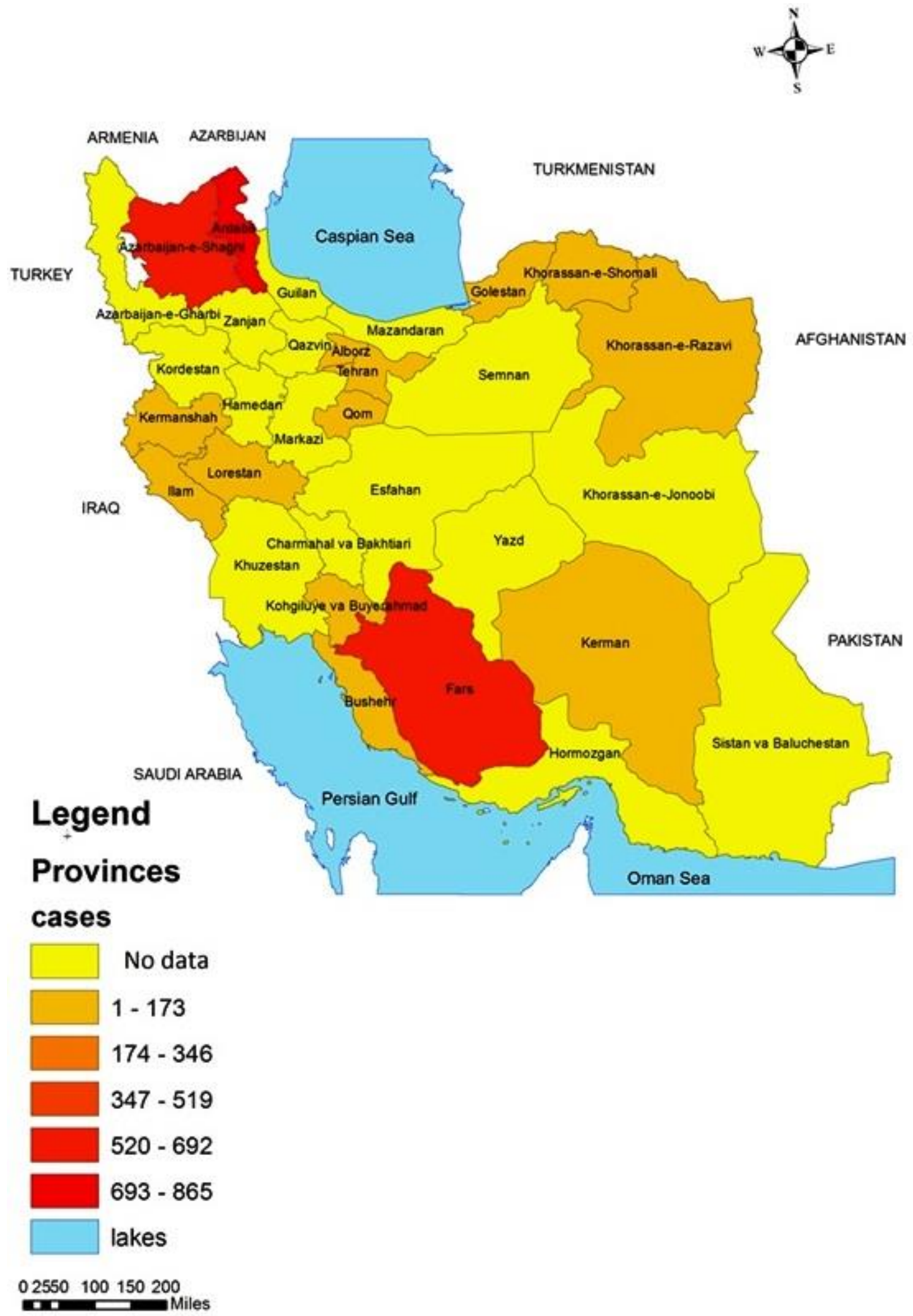

Figure 3. Plan of the total distribution of human VL in the states of the Islamic Republic of Iran 


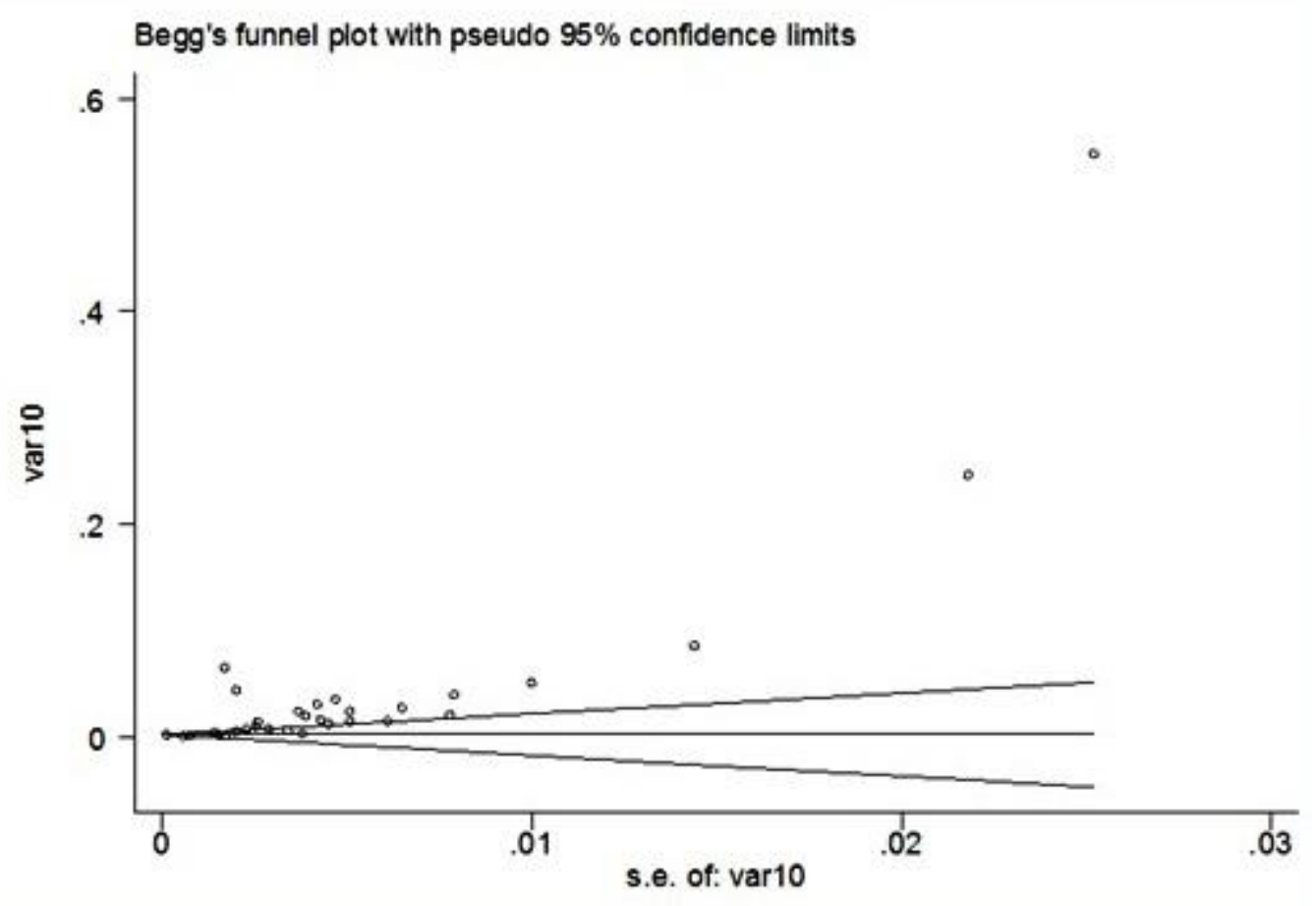

Figure 4. Egger's plot for the detection of publication bias in the review

Table 2. Comparison of common and corrected meta-analysis results for publication bias

\begin{tabular}{|c|c|c|c|c|c|}
\hline \multirow{2}{*}{$\begin{array}{c}\text { Number of } \\
\text { study }\end{array}$} & \multicolumn{2}{|c|}{$95 \% \mathrm{CI}$} & \multirow{2}{*}{$\begin{array}{c}\text { Pooled } \\
\text { seroprevalence }\end{array}$} & \multirow{2}{*}{ Method } & \multirow{2}{*}{ Type of meta-analysis } \\
\hline & Upper & Lower & & & \\
\hline \multirow[t]{2}{*}{29} & 0.003 & 0.002 & 0.002 & Fixed & \multirow{2}{*}{ Usual meta-analysis } \\
\hline & 0.030 & 0.020 & 0.025 & Random & \\
\hline \multirow{2}{*}{43} & 0.002 & 0.001 & 0.002 & Fixed & \multirow{2}{*}{ Filled meta-analysis } \\
\hline & 0.009 & -0.002 & 0.003 & Random & \\
\hline
\end{tabular}

\section{DISCUSSION}

Visceral leishmaniasis is one of the most malignant types of leishmaniasis that is considered to be a deadly parasitic infection in the endemic parts of the world, which affects annually from about 50,000 to 90,000 new cases. In 2015, more than $90 \%$ of patients described to the world health organization were reported in seven countries, including Brazil, Ethiopia, India, Kenya, Somalia, South Sudan, and Sudan (53).

The aim of the current study was to determine the seroprevalence of human VL in Iran since no metaanalysis related to this issue have been available so far.
Based on the results of this study, it seems that most of the VL cases have been recorded in the northwest (Ardebil, East Azerbaijan) and south (Fars and Bushehr) provinces of Iran over the past 33 years (Figure 3). These areas in Iran have already been known as endemic areas of visceral leishmaniasis (20, $51,54,55)$. These foci seem to be expanding in other parts of Iran (56) and major studies on the VL seroprevalence in these areas have also been con-ducted. The sporadic incidence of disease in other regions of Iran has also been reported in recent years (20). 
According to the Center for Infectious Diseases Control at the Ministry of Health in 2017, 58 definite cases of kala-azar were reported in Iran, with the highest frequency in East Azerbaijan (9 cases), Ardebil (8 cases) and Fars (6 cases) provinces, which confirms the results of this study. In the endemic form, the highest rate of infection is among the children, and out of 29 studies included in this review, only three studies have investigated the seroprevalence of VL in adolescents $(25,31,36)$, whereas other studies focused on the target group of children. Based on the results of some studies, the frequency of VL is associated with age $(14,51,57,58)$.

The results of the present study showed that the prevalence of VL in Iran was 1\% (95\% CI: 1 - 2) in urban areas and 4\% (95\% CI: 3 - 5) in rural areas, indicating a higher incidence of disease in rural areas of Iran compared with urban areas. The pooled prevalence of VL was estimated to be 3\% (95\% CI: 3 - 5) in Iran though Mohebali (20) reported a total incidence of VL to be $4.7 \%$ in five regions of Iran. Different seroprevalence has been reported in other studies based on the location of study, type of diagnostic method and sample size. Meta-analysis provides valuable results on the magnitude of the effects of the evaluated studies. However, if the results of a meta-analysis are an example of a bias in the studies in that field, then this bias will also have affected the results of meta-analysis (58).

Since the publication bias was significant in the current meta-analysis, after statistical correction, the Trim-and-fill method was used to correct the metaanalysis results, and the hypothetical values of 14 censored studies were estimated using non-parametric methods and then were reported as corrected values in the final meta-analysis. Finally, the corrected prevalence after the correction of publication bias was estimated to be $0.3 \%$ ( $95 \%$ CI: $0.2-0.9$ ) by randomeffects method. It can be seen that the estimated prevalence after the correction has decreased significantly, indicating that 14 censored studies are likely to be studies with low sample size or with negative results that have not been reported and published and therefore have resulted in publication bias.

However, the genetic factors probably accompanied with the infection should not be ignored. The results of a meta-analysis in the United States demonstrated a close association between VL and the life in poverty, the absence of urban substructure and sustainable services and a low educational level. This relationship between low socioeconomic conditions and VL risk can be described by the fact that the poor economic status is associated with more vectors, the irresponsibility of domesticated owners and the areas with a vegetation density suitable for the presence of vectors and possible reservoirs (58).

Lastly, although in a small number of studies, the variables linked to the geography of the environment and vegetation confirmed that the VL occurs more frequently in regions where the urbanization level is lower and the vegetation density is higher, possibly generating adequate habitats for breeding the vector population (59).

The infection rate in our bordering countries was as follows: in Pakistan (0.03 cases/10 000 population) (60) and in Saudi Arabia (0.01 cases/10 000 population) (61), which is less than the infection rate in Iran. Two other studies have reported the infection rate of $1.62 \%$ and $47.21 \%$ in suspected patients who were positive for visceral leishmaniasis, in Turkey (62) and Iraq (63), respectively.

Success in VL control programs requires the knowledge of the infection rate among human populations and reservoirs, as well as the awareness of active disease foci (64). Dogs are considered as the most important source and reservoir for VL in Iran. Shokri et al. (65), on the basis of a meta-analysis and systematic review, reported that the prevalence of VL in dogs, jackals, wolves and foxes in Islamic republic of Iran was $16.4 \%$ (95\% CI:15 - 20\%), 10\% (95\% CI: 5 - 15\%), 10\% (95\% CI: 5 - 15\%) and 10\% (95\% CI:1 - 19\%), respectively. The highest prevalence was in dogs of Ardebil province with the prevalence of $43.6 \%$. In the present study, Ardabil province has been also identified with high prevalence of human VL.

According to various studies, the use of direct agglutination test is one of the desirable, simple and practical methods for investigating VL seroepidemiology and animal reservoirs $(3,54,66,67)$. The most widely used diagnostic test in the majority of papers included in this study was DAT with a cut-off point of 1:3000, and only Faghar et al. (37) applied PCR in addition to DAT, whereas Alborzi et al. (49) employed two methods of PCR and IFAT to determine the VL separately in all of their subjects and reported the prevalence according to individual diagnostic methods.

If a target antigen is available, DAT test can be performed by a trained technician in remote areas with minimal laboratory facilities. The sensitivity of this method has been reported to be $92 \%-100 \%$ in endemic areas. Additionally, the patients with clinical signs 
suspected of kala-azar could undergo specific VL treatments without bone marrow or spleen puncture if this test is positive $(68,69)$.

It is necessary to mention some limitations in this study. Such an analysis is limited due to the heterogeneity among the results of various studies. Although an extensive search was done for doctoral theses done on this subject, it possible that many of them have not been published at all, which may be one of the reasons for the publication bias in the present study.

Also, an unequal sample size due to the demographic features in some studies caused this bias. A possible conclusion is that is the small sample size in some studies, therefore the infection rate, appears higher than the true rate.

\section{CONCLUSION}

The results of this meta-analysis showed that, after correcting the publication bias, the prevalence of VL in Iran was $0.3 \%$ (95\% CI: $0.2-0.9)$. The incidence rate of the VL over the past 33 years was higher in the northwest (Ardebil and East Azerbaijan) and south (Fars and Bushehr) provinces of Iran and these provinces have been considered as endemic VL foci in Iran.
These results are desirable for managing the control and prevention programs.

To control VL in Iran, it is recommended to manage stray dogs, to detect suspicious dogs of the disease by periodic DATs and to deal with them if serologically positive. It is also necessary to control the vectors, to diagnose quickly and timely human cases using serological tests, to treat infected people for reducing mortality and to develop the public health education.

\section{Conflict of interest}

The authors declare that they have no conflict of interest.

\section{Acknowledgements}

The authors hereby would like to express their gratitude and appreciation to Dr. Mohammad Heidari, Assistant Professor of Epidemiology at Urmia University of Medical Sciences, for collaboration and providing advice on the implementation of this meta-analysis in different stages and sections.

We would also like to thank for being financially supported by Vice-Chancellors for Research at Jahrom University of Medical Sciences. 


\section{References}

1. Rahmanian V, Rahmanian K, Sarikhani Y, et al. Epidemiology of Cutaneous Leishmaniasis, West South of Iran, 2006-2014. J Res Med Dent Sci 2018; 6:378-83. doi: $10.5455 /$ jrmds. 20186258

2. Palatnik-de-Sousa CB, dos Santos WR, FrancaSilva JC, et al. Impact of canine control on the epidemiology of canine and human visceral leishmaniasis in Brazil. Am J Trop Med Hyg 2001; 65:510-7.

\section{https://doi.org/10.4269/aitmh.2001.65.510}

3. Bokai S, Mobedi I, Edrissian GhH NA. Seroepidemiological study of canine visceral leishmaniasis in Meshkin-Shahr, northwest of Iran. Arch Inst Razi 1998; 41:48-9.

4. Bokaei S, Sharifi L, Mamishi S, et al. Clinical And Epidemiologic Characteristics Of Children With Kala-Azar Hospitalized In Children's Medical Center(1991-2003). Iran J Epidemiol.1:21-6.

5. Desjeux P. Leishmaniasis: current situation and new perspectives. Comp Immunol Microbiol Infect Dis 2004:27:305-18.

https://doi.org/10.1016/j.cimid.2004.03.004

6. Chappuis F, Sundar S, Hailu A, et al. Visceral leishmaniasis: what are the needs for diagnosis, treatment and control? Nat Rev Microbiol 2007;5: 7. https://doi.org/10.1038/nrmicro1748z

7. Mohebali M, Hajjaran H, Hamzavi $\mathrm{Y}$, et al Epidemiological aspects of canine visceral leishmaniosis in the Islamic Republic of Iran. Vet Parasitol 2005;129:243-51.

https://doi.org/10.1016/j.vetpar.2005.01.010

8. Yaghoobi-Ershadi M. Phlebotomine sand flies (Diptera: Psychodidae) in Iran and their role on Leishmania transmission. J Arthropod Borne Dis 2012;6:1.

9. Heydarpour F, Akbari Sari A, Mohebali M, et al. Economic burden of cutaneous and visceral lishmaniasis in Iran in 2013. Iran J Epidemiol 2017;13:1-13.

10. Heydarpour F, Sari AA, Mohebali M, et al. Incidence and Disability-Adjusted Life Years (Dalys) Attributable to Leishmaniasis In Iran, 2013. Ethiop J Health Sci 2016;26:381-8.

https://doi.org/10.4314/ejhs.v26i4.10

11. Asgari $Q$ Fakhar M, Motazedian H. Nomadic kala-azar in South of Iran. Iran J Public Health 2006;35:85-6.

12. Edrissian G, Hajjaran $H$, Mohebali $M$, et al. Application and evaluation of direct agglutination test in ser-diagnosis of visceral leishmaniasis in man and canine reservoirs in Iran. Iran J Med Sci 1996;21:119-24.

13. Alborzi A, Pouladfar GR, Fakhar M, et al. Isolation of Leishmania tropica from a patient with visceral leishmaniasis and disseminated cutaneous leishmaniasis, southern Iran. Am J Trop Med Hyg 2008;79:435-7.

https://doi.org/10.4269/ajtmh.2008.79.435

14. Nadim A, Navid-Hamidid A, Javadian E, et al. Present status of kala-azar in Iran. Am J Trop Med Hyg 1978;27:25-8.

https://doi.org/10.4269/ajtmh.1978.27.25

15. Motazedian $\mathrm{H}$, Noyes $\mathrm{H}$, Maingon $\mathrm{R}$. Leishmania and Sauroleishmania: the use of random amplified polymorphic DNA for the identification of parasites from vertebrates and invertebrates. Exp Parasitol 1996;83:150-4.

https://doi.org/10.1006/expr.1996.0059

16. Alborzi A, Pouladfar GR, Aelami MH. Visceral leishmaniasis; literature review and Iranian experience. Iran J Clin Infect Dis 2007;2:99-108.

17. Fakhar M, Ahmad Pour E. An Overview of theLaboratory Diagnostic Procedures of Visceral Leishmaniasis (Kala-Azar). Med Lab J 2013;7:45-54. 
18. Fakhar M, Rahmati B. Visceral leishmaniasis in Mazandaran province and Review on its current situation in Iran.j Babol univ med sci 2011;13:68-75

19. Sakkas H, Gartzonika C, Levidiotou S. Laboratory diagnosis of human visceral leishmaniasis. J Vector Borne Dis 2016;53:8.

20. Mohebali M. Visceral leishmaniasis in Iran: review of the epidemiological and clinical features. Iran J Parasitol 2013;8:348.

21. Spittal MJ, Pirkis J, Gurrin LC. Meta-analysis of incidence rate data in the presence of zero events. BMC Med Res Methodol 2015;15:42. https://doi.org/10.1186/s12874-015-0031-0

22. J. Sweeting M, J. Sutton A, C. Lambert P. What to add to nothing? Use and avoidance of continuity corrections in meta-analysis of sparse data. Stat med 2004;23:1351-75.

https://doi.org/10.1002/sim.1761

23. Cox D. The continuity correction. Biometrika 1970;57:217-9.

https://doi.org/10.1093/biomet/57.1.217

24. Asfaram S, Fakhar M, Mohebali $M$, et al. Asymptomatic human blood donors carriers of Leishmania infantum: potential reservoirs for visceral leishmaniasis in northwestern Iran. Transfus Apher Sci 2017;56:474-9.

https://doi.org/10.1016/j.transci.2017.06.001

25. Mohebali M, Edrissian GH, Shirzadi MR, et al. An observational study on the current distribution of visceral leishmaniasis in different geographical zones of Iran and implication to health policy. Trop Med Infect Dis 2011;9:67-74.

https://doi.org/10.1016/j.tmaid.2011.02.003

26. Faghinaeini F, Mohebali M, Javadian E. Epidemiology of visceral leishmaniasis in the Kordan region of Savojbolagh, Tehran province. J Shahid Beheshti Unive Med Sci 2002;7:9-15.

27. Ashkanifar S, Fata A, Aalami M, et al. Seroepidemiological Study Of Asymptomatic Visceral Leishmaniasis Among Children Living In Rural Areas Of North And Central Khorasan ,Iran. J Mashhad Univ Med Sci 2016;59:283-92.
28. Edrissian G, Mohebali M, Hajjaran H, et al. KalaAzar Case Tinding Using Direct Agglutination. j Public Health Res 2003;1:9-16.

29. Mohami M, Mohebali M, Keshavarz H, et al. Seroepidemiologic study of visceral leishmaniasis in Garmi county of Ardabil province. j Public Health Res 2006;4:45-55.

30. Sarkari B, Pedram N, Mohebali M, et al. Seroepidemiological study of visceral leishmaniasis in Booyerahmad district, south-west Islamic Republic of Iran. East Mediterr Health J 2010;16:1133-6.

https://doi.org/10.26719/2010.16.11.113

31. Shirmohammad S, Mohebali M, Ghalehbin BM, et al. Human visceral leishmaniasis: Seroprevalence survey of asymptomatic adults in an endemic area of Northwestern Iran. J Biostat Epidemiol 2017;2:136-42.

32. Fakhar M, Motazedian M, Hatam G, et al. Asymptomatic human carriers of Leishmania infantum: possible reservoirs for Mediterranean visceral leishmaniasis in southern Iran. Ann Trop Med Parasitol 2008;102:577-83.

https://doi.org/10.1179/136485908X337526

33. Fakhar M, Motazedian M, Asgari Q, et al. A New Endemic Focus of Visceral Leishmaniosis in Southeren IRAN. Armaghane Danesh J 2006;11:10313.

34. Chegeni-Sharafi A, Urmazdi H, Mohebali M, et al. Seroepidemiology of Visceral Leishmaniasis (Human Infection) by Direct Agglutination Method in the Miankooh Region of Poldokhtar, Lorestan. J Lorestan Univ of Med Sci 2005;7:31-5.

35. Fakhar M, Kia AA, Gohardehi $\mathrm{S}$, et al. Emergence of a new focus of visceral leishmaniasis due to Leishmania infantum in Golestan Province, north-eastern of Iran. J Parasit Dis 2014;38:255-9.

https://doi.org/10.1007/s12639-013-0307-4

36. Sarkari B, Gadami F, Shafiei R, et al. Seroprevalence of Leishmania infection among the healthy blood donors in kala-azar endemic areas of Iran. J parasit dis 2015;39:545-9.

https://doi.org/10.1007/s12639-013-0393-3 
37. Fakhar M, Motazedian M, Asgari $\mathrm{Q}$ et al. The efficacy of PCR for early diagnosis and detection of asymptomatic cases of visceral leishmaniasis in human and dog. J Jahrom Univ Med Sci 2010;8:1-7. https://doi.org/10.29252/jmj.8.2.1

38. Mahmoudvand H, Mohebali M, Sharifi I, et al. Epidemiological aspects of visceral leishmaniasis in Baft district, Kerman Province, Southeast of Iran. Iran J Parasitol 2011;6:1.

39. Fakhar M, Rahmati B, Gohardehi S, et al. Molecular and seroepidemiological survey of visceral leishmaniasis among humans and domestic dogs in Mazandaran province, north of Iran. Iran J Parasitol 2011;6:51.

40. Hamzavi Y, Hamzeh B, Mohebali M, et al. Human visceral leishmaniasis in Kermanshah province, western Iran, during 2011-2012. Iran J Parasitol 2012;7:49.

41. Heidari A, Mohebali M, Kabir K, et al. Visceral leishmaniasis in rural areas of Alborz province of Iran and implication to health policy. Korean J Parasitol 2015;53:379.

https://doi.org/10.3347/kjp.2015.53.4.379

42. Layegh Gigloo A, Sarkari B, Rezaei Z, et al. Asymptomatic Leishmania Infected Children: A Seroprevalence and Molecular Survey in a Rural Area of Fars Province, Southern Iran. J trop med 2018;15:1-6.

https://doi.org/10.1155/2018/8167247

43. Masoori L, Kheirandish F, Haghighi A, et al. Molecular-Based Detection of Leishmania infantum in Human Blood Samples in a New Focus of Visceral Leishmaniasis in Lorestan Province, Iran. J Arthropod Borne Dis 2018;12:67.

44. Ebrahimzade-Parikhani H, Mohebali M, Zarei Z, et al. Seroprevalence of visceral leishmaniasis in children up to 12 years old among nomadic tribes from rural areas of Pars Abad, northwestern Iran: an observational study in 2015. J Arthropod Borne Dis 2017;11:331.

45. Jahangir A, Akhoundi B, Mohebali M, et al. Seroepidemiological survey of human visceral leishmaniasis in Ilam province, west of Iran in 2013. Iran J Parasitol 2015;10:56.

46. Khazaei S, Mohebali M, Akhoundi B, et al. Seroprevalence survey of visceral leishmaniasis among children up to 12 years old and domestic dogs in rural areas of Dehloran District, Ilam Province of west part of Iran, 2014. Novelty in Biomedicine 2017;5(2):78-84.

https://doi.org/10.22037/nbm.v5i2.13047

47. Gorgipoor M, Mohebali M, Akhoundi B, et al. Human Visceral Leishmaniasis: a Serological Survey in Rural Areas of Dashti District of Bushehr Province, Southern Iran. Novelty in Biomedicine 2017;5:54-8.

https://doi.org/10.22037/nbm.v5i2.13491

48. Mirsamadi N, Mohebali M, Atari M, et al. Serological survey of Visceral leishmaniasis (kalaazar) in Azarshahr, Azarbaijan province, northwest of Iran.Hakim Res J 2003;6:17-25

49. Alborzi A, Pourabbas B, Shahian F, et al. Detection of Leishmania infantum kinetoplast DNA in the whole blood of asymptomatic individuals by PCR-ELISA and comparison with other infection markers in endemic areas, southern Iran. Am J Trop Med Hyg 2008;79:839-42.

https://doi.org/10.4269/ajtmh.2008.79.839

50. Torabi V, Mohebali M, Edrissian G, et al. Seroepidemiology Of Visceral Leishmaniasis By Direct Agglutination Method In Bojnourd City Of North Khorasan Province In 2007. Iran J Epidemiol 2008;4:43-50.

51. Mohebali M, Hamzavi Y, Edrissian GH, et al. Seroepidemiological study of visceral leishmaniasis among humans and animal reservoirs in Bushehr province, Islamic Republic of Iran. East Mediterr Health J2001;7:912-7

52. Rakhshanpour A, Mohebali M, Akhondi B, et al. Serological Survey and Associated Risk Factors of Visceral Leish-maniasis in Qom Province, Central Iran. Iran J Public Health 2014;43:50.

53. Visceral leishmaniasis [Internet]. who.int. [cited 1 August 2018]. Available from: 
http://www.who.int/news-room/factsheets/detail/leishmaniasis.

54. Mohebali M, Edrissian G, Nadim A, et al. Application of direct agglutination test (DAT) for the diagnosis and seroepide-miological studies of visceral leishmaniasis in Iran. Iran J Parasitol 2006;1:15-25.

55. Edrissian GH, Ahanchin A, Gharachahi A, et al. Seroepidemiological studies of visceral leishmaniasis and search for animal reservoirs in Fars province, southern Iran. Iran J Med Sci 1993;18:99-105.

56. Fakhar M, Mohebali M, Barani M. Introduction of an endemic focus of kala-azar in Ghom province and seroepidemiological survey on visceral leishmaniasis in human and animal reservoirs (dogs) in this area. Armaghane-danesh J 2004;33:43-52.

57. Mohammadi-Kheyrabadi K, Mohebali M, Mamishi S, et al. Epidemilogical Characteristics Of Kala-Azar In Hospitalized Patients In Ardebil Province. J public Health Res 2004;2:11-24.

58. Belo VS, Werneck GL, Barbosa DS, et al. Factors associated with visceral leishmaniasis in the americas: a systematic review and meta-analysis. PLoS Negl Trop Dis 2013;7:e2182. https://doi.org/10.1371/journal.pntd.0002182

59. Lainson R, Rangel EF. Lutzomyia longipalpis and the eco-epidemiology of American visceral leishmaniasis, with particular reference to Brazil: a review. Mem Inst Oswaldo Cruz 2005;100:811-27. https://doi.org/10.1590/S0074-02762005000800001

60. Ertabaklar H, Ozensoy Toz S, Taylan Ozkan A, et al. Serological and entomological survey in a zoonotic visceral leishmaniasis focus of North Central Anatolia, Turkey: Corum province. Acta Trop 2005;93:239-46.

https://doi.org/10.1016/j.actatropica.2005.01.002

61. Rahi AA, Ali MA, Valian HK, et al. Seroepidemiological studies of visceral leishmaniasis in Iraq. Sch J App Med Sci 2013;1:985-9.

https://doi.org/10.11648/j.ajbio.20130101.11
62. Leishmaniasis in Pakistan. [Internet]. who.int. [cited 2 August 2018]. Available from: http://www.who.int/leishmaniasis/resources/Pakista n CP 2014.pdf?ua=1\&ua=1.

63. Leishmaniasis in Saudi Arabia. [Internet]. who.int. [cited 2 August 2018]. Available from: http://www.who.int/leishmaniasis/resources/Saudi Arabia CP 2014.pdf.

64. Ashford DA, David JR, Freire M, et al. Studies on control of visceral leishmaniasis: impact of dog control on canine and human visceral leishmaniasis in Jacobina, Bahia, Brazil. Am J Trop Med Hyg 1998;59:53-7.

https://doi.org/10.4269/ajtmh.1998.59.53

65. Shokri A, Fakhar M, Teshnizi SH. Canine visceral leishmaniasis in Iran: a systematic review and metaanalysis. Acta Trop 2017;165:76-89.

https://doi.org/10.1016/j.actatropica.2016.08.020

66. Cardoso Ls, Rodrigues M, Santos H, et al. Seroepidemiological study of canine Leishmania spp. infection in the municipality of Alijó (Alto Douro, Portugal). Vet Parasitol 2004;121:21-32.

https://doi.org/10.1016/j.vetpar.2004.02.008

67. Edrissian $\mathrm{GhH}$, Hajjaran $\mathrm{H}$, Mohebali M, et al. Application and evaluation of direct agglutination test in ser-diagnosis of visceral leishmaniasis in man and canine reservoirs in Iran. Iran J Med Sci 1996;21:119-24.

68. Andrade C, Silva O, Andrade $\mathrm{P}$, et al. A direct agglutination test discriminative toward Chagas' disease for the diagnosis of visceral leishmaniasis in Brazil: preliminary results. Ann Inst Pasteur Immunol 1987:138:457-9.

https://doi.org/10.1016/S0769-2625(87)80056-9

69. Boelaert M, Lynen L, Desjeux P, et al. Costeffectiveness of competing diagnostic-therapeutic strategies for visceral leishmaniasis. Bull World Health Org 1999;77:667. 


\title{
Sistematični pregled i metaanaliza humane visceralne leišmanijaze u Iranu
}

\author{
Vahid Rahmaniann ${ }^{1}$ Karamatollah Rahmanian ${ }^{1}$, Abdolreza Sotoodeh Jahromi ${ }^{1}$, Saied Bokaie ${ }^{2}$ \\ ${ }^{1}$ Centar za ispitivanje zoonoza, Univerzitet medicinskih nauka u Jahromu, Jahrom, Iran \\ ${ }^{2}$ Departman za epidemiologiju, Fakultet veterinrske medicine, Univerzitet u Teheranu, Teheran, Iran
}

\section{SAŽETAK}

Visceralna leišmanijaza je parazitska bolest izazvana vrstom Leishmania donovani i smatra se endemskom zoonozom u Iranu. Cilj ove studije bilo je određivanje prevalencije humane visceralne leišmanijaze $\mathbf{u}$ Iranu. Podaci su sistematično prikupljeni za period od 1985. godine do 2018. godine u islamskoj republici Iran, iz sledećih elektronskih baza: PubMed, Google Scholar, Science Direct, Scopus, Web of Science, Magiran, Irandoc, Iranmedex and Scientific Information Database (SID). Naše kriterijume zadovoljilo je ukupno 29 studija, koje su izveštavale o prevalenciji visceralne leišmanijze u različitim delovima Irana. Za određivanje heterogenosti korišćeni su $Q$ test kao i I2 statistika. Egerov i Begov test primenjen je kako bi se utvrdila pristrasnost publikovanja. Zbirna, prosečna_prevalencija visceralne leišmanijaze merena modelom slučajnog efekta procenjena je na 1\% (95\% CI: 1 - 2) u gradskim sredinama, 3\% (95\% CI:2 - 4) u ruralnim sredinama i 2\% (95\% CI: 2 3) ukupno.

Najveći broj slučajeva visceralne leišmanijaze u poslednje 33 godine zabeležen je u severozapadnim $\mathbf{i}$ južnim provincijama Irana. Utvrđen je visok stepen heterogenosti (I2 $=98.2 \%, Q$ test: $p=0,0002)$; Begovi i Egerovi testovi bili su značajni kod utvrđivanja pristrasnosti publikovanja. Nakon korekcije, ukupna prevalencija procenjena je na $0,3 \%(95 \%$ CI: 0,2 - 0,9). Prevalencija visceralne leišmanijaze u Iranu bila je $0,3 \%$. Ova stopa bila je znatno viša u severozapadnim i južnim delovima zemlje. Ovi podaci su korisni za uvođenje programa kontrole bolesti.

Ključne reči: crna groznica, Leishmania infantum, prevalencija, Iran 